\title{
Socio-Demographic Determinants of Response Strategies by Resource-Poor Farmers to Climate Change in South-Eastern Nigeria
}

\author{
Asuquo I. Afangideh \\ Department of Geography and Regional Planning, University of Calabar \\ PMB 1115, Calabar, Nigeria \\ Phillip A. Akpan \& Emmanuel P. Udofia \\ Department of Geography, University of Uyo, Akwa Ibom State, Nigeria
}

Donald A. Ukeh (Corresponding author)

Department of Crop Science, University of Calabar

PMB 1115, Calabar, Nigeria

\author{
Received: September 20, $2011 \quad$ Accepted: October 13, $2011 \quad$ Published: March 1, 2012 \\ doi:10.5539/jgg.v4n1p33 URL: http://dx.doi.org/10.5539/jgg.v4n1p33
}

\begin{abstract}
Direct and indirect socio-demographic attributes of the resource-poor farmers were determined in the study as potential controls of reactive and/or autonomous response to climate change. One thousand five hundred (1500) farming households $(\mathrm{FH})$ were randomly drawn from six thousand (6000) estimated population of study in sixty (60) farming communities (FC) with the multi-stage survey research design. The critical path analytical technique with the multiple regression analysis backward solution was utilized to enhance understanding of patterns of relationships between eight socio-demographic variables. The variables were age of respondent, sex, educational level, average monthly income, cropping experience, crops grown, cropping pattern, farm enterprise and the response strategy/capacity (dependent variables). The sex, age and farm enterprise of respondent was shown to have $66 \%$ direct influence on the response capacity of the farmers, while the remaining five variables have accumulative $66 \%$ indirect effects. The direct socio-demographic factors that seemed more potent are suggested in planning adaptive responses built up to climate change for the farmers.
\end{abstract}

Keywords: Climate change, Determinants, Structural equations, Exogenous variables, Paths coefficients

\section{Introduction}

Climate describes weather patterns for a given location over an extended period of time. Climate is not just the average conditions of temperature and precipitation but also the seasonal and annual weather variation, including the frequency and severity of extreme events such as storms, gale or drought. The Earth's climatic patterns are now changing and there is increasing concern about how human activities are contributing to climate changes (McCarty et al., 2009). Impacts of climate change include increased dry conditions, crop failure, low forage, reduced livestock productivity and increased livestock and human diseases (Begum et al., 2011; Mwangombe et $a l ., 2011)$. There are considerable variations at the global scale among countries with regard to their capacity to adapt to climate change. Given their economic influence and stability, institutions and infrastructures, their access to capital, information, and technology, developed nations are broadly considered to have greater capacity to adapt than developing regions or countries in economic transition (Goklany, 1995; Burton, 1997; Begum et al., 2011). Progress in agriculture, industry, transportation and technology are usually the barometer of economic development of any nation (Ene and Agbazue, 2011). Generally, countries with well-developed social institutions supported by higher levels of capital and human knowledge are considered to have greater adaptive capacity (Smith and Lenhart, 1996). Adaptation options including traditional coping strategies often are available in developing countries. In practice, however, those countries capacity to effect timely response actions may be beyond their infrastructure and economic means (IPCC, 2007). For those countries and societies, their 
main barriers according to Smith (1996) are financial, institutional, socio-cultural, technological, information and educational.

A study by Rosenzweig and Parry (1994) reported considerable disparity between developed and developing countries in terms of potential adverse effects of climate change on agricultural systems. Poorer developing societies or regions presumably will face stricter constraints on technology and institutions (Frankhauser and Tol, 1997) and measures taken in response to climate change could have adverse financial implications (Afangideh, 2010). It has also been reported that developing countries possess a lower adaptive capacity as a result of greater reliance on climate resources compared to industrialized countries (Schelling, 1992; Frankhauser and Tol, 1997).

This study investigate socio-cultural and ethnic institutions as well as gender, demographic, economic and religious characterizations that are likely elements strong enough to influence human attitude and response or reaction to environmental stimuli. In particular, the unique sub-Saharan settings of this study against those viewed from other climes provide full and complete perspectives to the issue. The desire of people on adaptive responses to climate change is regarded as a holistic approach and indirect socio-demographic factors influencing response strategies and how they could be modelled for possible management purposes.

The main objective of this study was to investigate the direct and indirect factors influencing the adaptive response strategies of resource poor farmers in South-Eastern Nigeria.

\section{Methodology}

\subsection{Study Area}

The study was conducted across three states namely Akwa Ibom, Cross River and Abia based on the agro-ecological zones sculptured from the Agricultural Development Projects (ADP) of the Federal Government of Nigeria. The sampled states (Fig. 1) fall within the tropical rainforest vegetation belt with high tropical forest especially in the Cross River State's segment. Climatologically, the area lies within latitudes $4^{\circ} 32^{\prime}$ and $7^{\circ} 15^{\prime}$ north of the equator. The southern tip of the area usually experience 8 months of annual rainfall from April October. The mean annual rainfall is over $2500 \mathrm{~mm}$ generally except northern Cross River with about $1500 \mathrm{~mm}$. Average annual temperatures are in the range of $23.4-39.69^{\circ} \mathrm{C}$ (Udoidung et al., 2007; Ukeh, 2008).

\subsection{Research Design and Population of Study}

The survey research design was adopted for the study because it was economical and systematic while data obtained were representative of the population studied, and collected by trained field personnel. Twelve (12) agro-ecological zones comprising 500 farmer populations each formed our population of study. In each of the three states, two zones comprising 250 respondent arable crops farmers from two local government areas (LGA) (125 each) were chosen as the sample of study. This gave a total of 1500 respondents to the survey (Table 1).

\subsection{Sample Technique, Instrumentation and Reliability of Instrument}

The study utilizes the questionnaire, unrestricted, unstructured interview and participant observation methods to collect the necessary data. Such structured questionnaire sought the respondents' opinion, knowledge or suggestions on the subject. The questionnaires involved the close and open-ended format and are structured in a manner to cover all the variables under consideration. The questionnaire was also tested for validity using a pilot survey technique where 150 respondent farmers in the zones were administered representing $10 \%$ of the respondents. Modifications were made after the exercise and some items in the questionnaire were re-structured.

\subsection{Data Analysis - The Critical Paths Analytical Technique}

The linear relationship between socio-demographic variables and the dependent variables (adaptation strategies) formed the basis for hypothesizing the existence of a theoretical relationship with nine socio-demographic variables. Causal modelling was the technique for selecting those variables that were perceived to be determinant causes and effects, and then isolating the separate contributions made by each cause through Critical Paths Analysis Coefficient. The basic aim of the Path Analysis Technique in this study was to enable our understanding of patterns of relationships between the eight (8) socio-demographic variables and the dependent variable. The hypothesized path model which addressed the linkages between the sets of variables in the study is presented;

$\mathrm{X}_{1}=$ Sex

$\mathrm{X}_{2}=$ Age

$\mathrm{X}_{3}=$ Educational level

$\mathrm{X}_{4}=$ Average monthly income 
$\mathrm{X}_{5}=$ Cropping experience in year

$\mathrm{X}_{6}=$ Crops grown

$\mathrm{X}_{7}=$ Cropping pattern

$\mathrm{X}_{8}=$ Farm enterprise

$\mathrm{X}_{9}=$ Adaptation

A confirmatory model that required the selection of the most meaningful paths diagram for all possible one (Johnston, 1980) was also utilized. In the present study, there were 28 paths (Fig. 2); the structural equations are presented below.

$\mathrm{X}_{4}=\mathrm{P}_{43} \mathrm{X}_{3}+\mathrm{P}_{54} \mathrm{X}_{4}+\mathrm{e}_{4}$;

$\mathrm{X}_{5}=\mathrm{P}_{53} \mathrm{X}_{3}+\mathrm{P}_{54} \mathrm{X}_{4}+\mathrm{e}_{5}$

$\mathrm{X}_{6}=\mathrm{P}_{61} \mathrm{X}_{1}+\mathrm{P}_{62} \mathrm{X}_{2}+\mathrm{P}_{63} \mathrm{X}_{3}+\mathrm{P}_{64} \mathrm{X}_{4}+\mathrm{P}_{65} \mathrm{X}_{5}+\mathrm{e}_{6}$;

$\mathrm{X}_{7}=\mathrm{P}_{71} \mathrm{X}_{1}+\mathrm{P}_{72} \mathrm{X}_{2}+\mathrm{P}_{73} \mathrm{X}_{3}+\mathrm{P}_{74} \mathrm{X}_{4}+\mathrm{P}_{75} \mathrm{X}_{5}+\mathrm{P}_{76} \mathrm{X}_{6}+\mathrm{e}_{7} ;$

$\mathrm{X}_{8}=\mathrm{P}_{81} \mathrm{X}_{1}+\mathrm{P}_{82} \mathrm{X}_{2}+\mathrm{P}_{83} \mathrm{X}_{3}+\mathrm{P}_{84} \mathrm{X}_{4}+\mathrm{P}_{85} \mathrm{X}_{5}+\mathrm{e}_{8}$;

$X_{9}=P_{91} X_{1}+P_{92} X_{2}+P_{93} X_{3}+P_{94} X_{4}+P_{95} X_{5}+P_{96} X_{6}+P_{97} X_{7}+P_{98} X_{8}+e_{8}$

Where $e_{t}, e_{2}, e_{3} \ldots e_{n}$ are the residual variables indicating effects of variables outside the model that are not accounted for by the independent variables. $\mathrm{P}_{41}, \mathrm{P}_{42}, \mathrm{P}_{43} \ldots \mathrm{P}_{\mathrm{n}}$ are paths drawn from variables taken as causes (independents) exogenous to variables taken as effects dependent (endogenous). To be meaningful, the absolute value of the paths coefficient must be at least 0.05 .

\section{Results and Discussion}

The results of critical path analysis procedure utilizing the multiple regression analysis backward solution showed that the linear relationships existing between the exogenous and endogenous variables are related. The respondents' age, sex and educational levels constituted the first set of exogenous variables while the intermediate exogenous variables comprise the average monthly income, years of cropping experience, type of crops grown, cropping pattern, and type of farm enterprise. The hypothesized six equations (Table 2) with 28 paths, standard paths coefficients and probability levels are derived. The results (Table 3 ) indicate that three exogenous variables $\left(\mathrm{X}_{15}, \mathrm{X}_{2}\right.$ and $\left.\mathrm{X}_{8}\right)$ out of the hypothesized 8 have direct influence on the respondents' adaptive capabilities. The exogenous variables $\mathrm{X}_{8}$ (farm enterprise) has the highest direct influence of 0.115 followed by variables $\mathrm{X}_{1}$ (sex) and $\mathrm{X}_{2}$ (age) in that order. The other five exogenous variables namely; educational qualification $\left(\mathrm{X}_{3}\right)$, average monthly income $\left(\mathrm{X}_{4}\right)$, years of cropping experience $\left(\mathrm{X}_{5}\right)$, crops grown $\left(\mathrm{X}_{6}\right)$, and cropping pattern $\left(\mathrm{X}_{7}\right)$ have no direct effects. The analysis also shows that the total effect and the proportion of it that are direct were $60 \%$ while the indirect were $66.53 \%$.

Human systems adaptation can be motivated by private or public interests. Private decision makers include individual household businesses and corporations, public interests are served by governments at all levels (Smith and Lenhart, 1996). Studies have shown that autonomous adaptations tend to be incremental, short termed and constrained by economic, social, cultural, technological, institutional, information and skills (Afangideh, 2006). In Iran, similar studies have shown that farmers with greater amount of irrigated land for agricultural purposes had better perception, adoption and knowledge regarding sustainable water resources management (Ommani, 2011). Similarly, in the sub-Saharan Kibwezi district of Kenya, the agro-pastoralists households have developed both short and long term adaptive response mechanisms to trends in climate change including planting of drought tolerant and early maturing crops, water harvesting, destocking of herds and change of herd composition (Mwangombe et al., 2011). The determinations of the direct and indirect influences of the resource poor farmer can, to a great extent enhance the process of effective management and policy formulations. The socio-demographic variables with the direct influences include sex, age and farm enterprise while those with indirect influences are educational qualification, average monthly income, years of cropping experiences, crop grown and cropping patterns. This result is contrary to the reports of Burton (1997) who reported that whatever is expressed as economic asset, capital resources, financial means, wealth or poverty, the economic condition of nations and groups clearly are determinants of adaptive capacity. In this study, the resource poor subsistence farmers did not have the same adaptive options as their commercial counterparts (Burton, 1997). Rather the identified exogenous variables with direct effect suggest that the respondents for obvious monetary reasons did not consider the issues of climate change adaptation enough to warrant financial commitments for a solution. 
Notwithstanding, the total exogenous influence of $60 \%$ with few direct variables suggests an equally greater influence compared with the relatively more indirect factors on their influence to the problem.

In conclusion, response capabilities and strategies of farmers due to climate change could include the socio-demographic characteristics of the farmer. Therefore the established direct variables and the average income of respondents are important factors to be considered when interventions and directions are to be extended to communities or regions under climate change.

\section{References}

Afangideh, A. I. (2006). The awreness and response of farmers to changing rainfall regime in parts of South-eastern Nigeria. Unpublished PhD Thesis, University of Uyo, Nigeria.

Afangideh, A. I. (2010). The attitude of food crop farmers to changing rainfall regime inparts of Cross River State, Nigeria. (in press).

Begum, R. A., Siwar, C., Abidin, R. D. Z. R. Z., et al. (2011). Vulnerability of climate change and hardcore poverty in Malaysia. Journal of Environmental Science and Technology, 4, 112-117. http://dx.doi.org/10.3923/jest.2011.112.117

Burton, H. M. (1997). Vulnerability and adaptive responses in the control of climate change. Climate Change, 36, 185-196. http://dx.doi.org/10.1023/A:1005334926618

Ene, O. C. \& Agbazue, V. C. (2011). Protection of Nigeria's environment: a critical policy review. Journal of Environmental Science and Technology, 4, 490-497. http://dx.doi.org/10.3923/jest.2011.490.497

Frankhauser, S. \& Tol, R. S. J. (1997). The social coat of climate change: The IPCC second assessment report and beyond. Mitigation and Adaptive Strategies for Global Change, 1, 385-403. http://dx.doi.org/10.1007/BF00464889

Goklany, I. M. (1995). Strategy to enhance adaptability: technological change, sustainable growth and free trade. Climate Change, 30, 427-449. http://dx.doi.org/10.1007/BF01093855

IPCC. (2007). Climate change 2007: synthesis report. In: Core Writing Team, Pachauri, R. K. and Reisinger, A. (eds) Contribution of Working Groups I, II and III to the Fourth Assessment Report of the Intergovernmental Panel on Climate Change, p. 104. Geneva, Switzerland: IPCC.

Johnston, R. J. (1980). Multivariate Statistical Analysis in Geography. London: Longman.

McCarty, J. P., Wolfenbarger, L. L. \& Wilson, J. A. (2009). Biological Impacts of Climate Change. In: Encyclopedia of Life Sciences (ELS). Chichester: John Wiley \& Sons, Ltd. http://dx.doi.org/10.1002/9780470015902.a0020480

Mwangombe, A. W., Ekaya, W. N., Muiru, W. M., et al. (2011). Livelihoods under climate variability and change: An analysis of the adaptive capacity of rural poor to water scarcity in Kenya's drylands. Journal of Environmental Science and Technology, 4, 403-410.

Ommani, A. R. (2011). Affecting factors on adoption of sustainable water resources management in Agriculture. Research Journal of Environmental Science, 5, 36-48. http://dx.doi.org/10.3923/rjes.2011.36.48

Rosenzweig, C. \& Parry, M. L. (1994). Potential impacts of climate change on world food supply. Nature, 67, 133-139. http://dx.doi.org/10.1038/367133a0

Schelling, T. C. (1992). Some economics of global warming. The American Economics, 82, 1-14.

Smith, J. B. \& Lenhart, S. S. (1996). Climate change adaptation policy options. Climate Research, 6, 193-201. http://dx.doi.org/10.3354/cr006193

Smith, K. (1996). Environmental hazards: assessing risk and reducing disasters, Rontledge, London.

Udoidung, N. I. G., Braide, I. E., Opara, K. N., et al. (2007). Perstans filariasis in rural communities of the lower Cross River basin Nigeria: parasitological observations. International Journal of Zoological Research, 3(4), 207-212. http://dx.doi.org/10.3923/ijzr.2007.207.212

Ukeh, D. A., (2008). Bioactivities of essential oils of Aframomum melegueta and Zingiber officinale both (Zingiberaceae) against Rhyzopertha dominica (Fabricius). Journal of Entomology, 5(3), 193-199. http://dx.doi.org/10.3923/je.2008.193.199 
Table 1. Sampling administration and collection of questionnaire

\begin{tabular}{|l|l|l|l|l|l|}
\hline LGAs & Number & Number & Number & Number & \% Response \\
\hline & Administered & Returned & Rejected & Used & \\
\hline Ohafia & 125 & 113 & 8 & 105 & 84 \\
\hline Arochukwu & 125 & 108 & 6 & 102 & 81.6 \\
\hline Umuahia & 125 & 121 & 14 & 107 & 85.6 \\
\hline Isiala Ngwa North & 125 & 101 & 0 & 101 & 80.8 \\
\hline Abak & 125 & 114 & 2 & 112 & 89.6 \\
\hline Ukanafun & 125 & 123 & 4 & 119 & 95.2 \\
\hline Oron & 125 & 102 & 6 & 96 & 76.8 \\
\hline Okobo & 125 & 98 & 0 & 98 & 78.4 \\
\hline Ogoja & 125 & 111 & 0 & 111 & 88.8 \\
\hline Obanliku & 125 & 120 & 11 & 109 & 87.2 \\
\hline Akpabuyo & 125 & 108 & 5 & 103 & 82.4 \\
\hline Akamkpa & 125 & 12 & 7 & 116 & 92.8 \\
\hline Total & 1500 & 1342 & 63 & 1279 & 85.28 \\
\hline
\end{tabular}

Table 2. Standardized paths coefficients and probalilities

\begin{tabular}{|l|l|l|l|l|}
\hline Paths & Standardized & P-Value & Zero order & Diff. \\
\hline & paths Coeff. & & & \\
\hline P43 & 0.123 & 0.001 & 0.123 & 0 \\
\hline P53 & -0.167 & 0.001 & -0.164 & -0.003 \\
\hline P54 & 0.025 & 0.37 & 0.004 & 0.021 \\
\hline P61 & 0.06 & 0.032 & 0.066 & 0.006 \\
\hline P62 & 0.044 & 0.126 & -0.041 & 0.003 \\
\hline P63 & -0.06 & 0.037 & -0.085 & -0.025 \\
\hline P64 & -0.109 & 0.001 & 0.103 & 0.005 \\
\hline P65 & 0.022 & 0.452 & 0.038 & 0.016 \\
\hline P71 & 0.108 & 0.001 & 0.103 & 0.005 \\
\hline P72 & 0.013 & 0.001 & 0.032 & 0.019 \\
\hline P73 & 0.045 & 0.112 & 0.04 & 0.003 \\
\hline P74 & 0.089 & 0.002 & 0.094 & 0.005 \\
\hline P75 & 0.038 & 0.187 & 0.031 & 0.007 \\
\hline P76 & 0.1 & 0.76 & 0.005 & 0.005 \\
\hline P81 & -0.091 & 0.001 & -0.089 & -0.002 \\
\hline P82 & -0.135 & 0.001 & 0.125 & 0.01 \\
\hline P83 & -0.103 & 0.001 & 0.142 & 0.039 \\
\hline P84 & 0.248 & 0.001 & 0.274 & 0.026 \\
\hline P85 & -0.166 & 0.001 & -0.148 & 0.018 \\
\hline P86 & 0.069 & 0.009 & 0.026 & \\
\hline
\end{tabular}




\begin{tabular}{|l|l|l|l|l|}
\hline P91 & 0.061 & 0.03 & 0.074 & 0.013 \\
\hline P92 & -0.098 & 0.001 & -0.083 & -0.015 \\
\hline P93 & 0.14 & 0.632 & -0.007 & 0.007 \\
\hline P94 & 0.15 & 0.61 & 0.001 & 0.014 \\
\hline P95 & 0.025 & 0.383 & 0.012 & 0.013 \\
\hline P96 & 0.039 & 0.167 & 0.04 & 0.001 \\
\hline P97 & -0.011 & 0.72 & 0.119 & 0.109 \\
\hline P98 & 0.115 & 0.001 & -0.02 & 0.089 \\
\hline
\end{tabular}

Table 3. Proportion of direct and indirect effect

\begin{tabular}{|l|l|l|l|l|l|}
\hline Variables & Total & Direct & \% direct & Indirect & \% indirect \\
\hline & effect & effect & effect & effect & effect \\
\hline X1 & 0.074 & 0.061 & 46.92 & 0.013 & 10 \\
\hline X2 & -0.083 & -0.094 & -75.38 & -0.181 & -139.23 \\
\hline X3 & -0.007 & 0 & 0 & -0.007 & -5.4 \\
\hline X4 & 0.001 & 0 & 0 & 0.001 & 0.77 \\
\hline X5 & 0.012 & 0 & 0 & 0.012 & 9.23 \\
\hline X6 & 0.04 & 0 & 0 & 0.04 & 30.77 \\
\hline X7 & 0.026 & 0 & 0 & 0.089 & 68.85 \\
\hline X8 & -0.117 & 0.115 & 88.46 & 0.119 & 91.57 \\
\hline Total & 0.13 & 0.078 & 60 & 0.086 & 66.53 \\
\hline
\end{tabular}




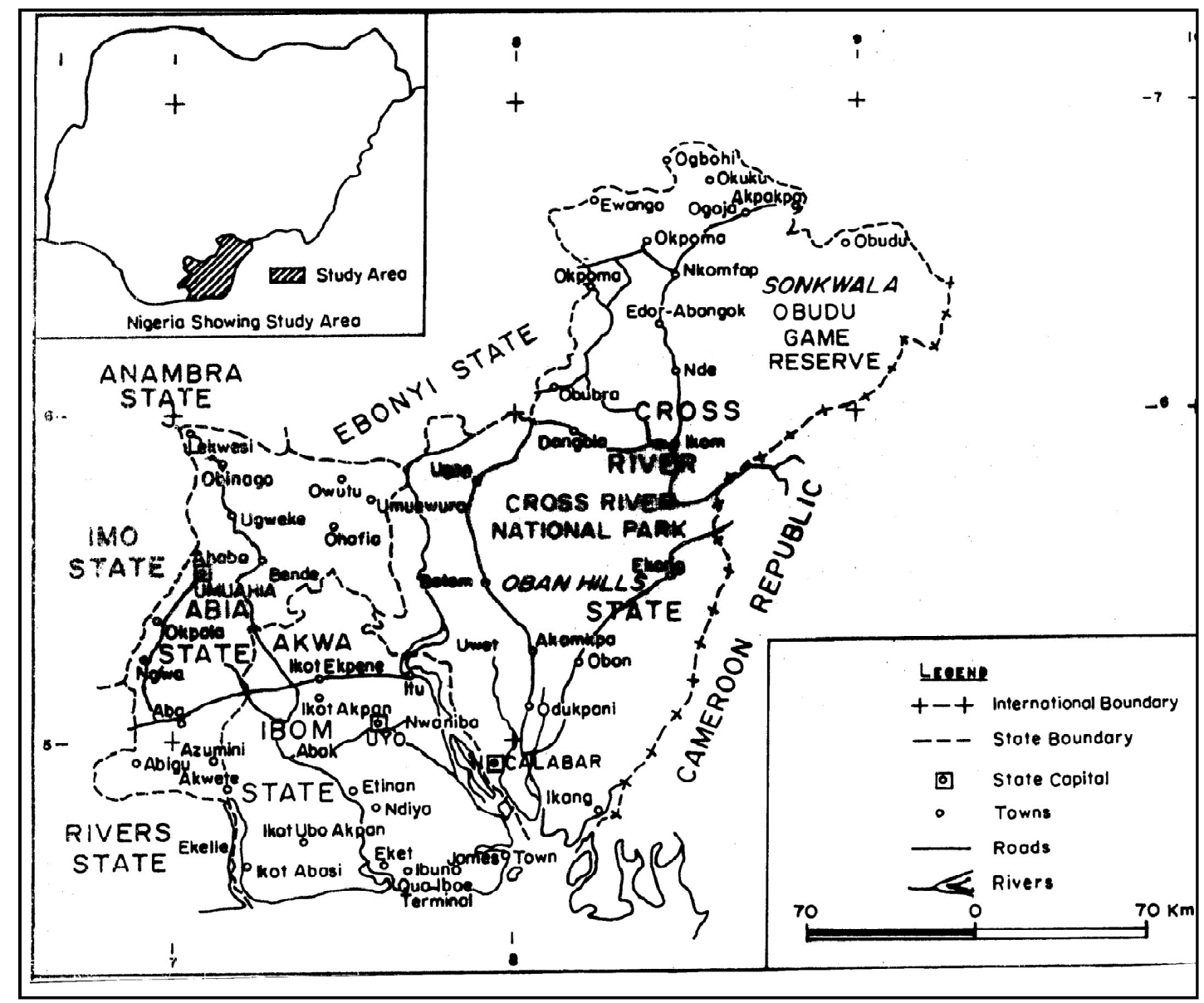

Figure 1. Map of Nigeria showing study area 


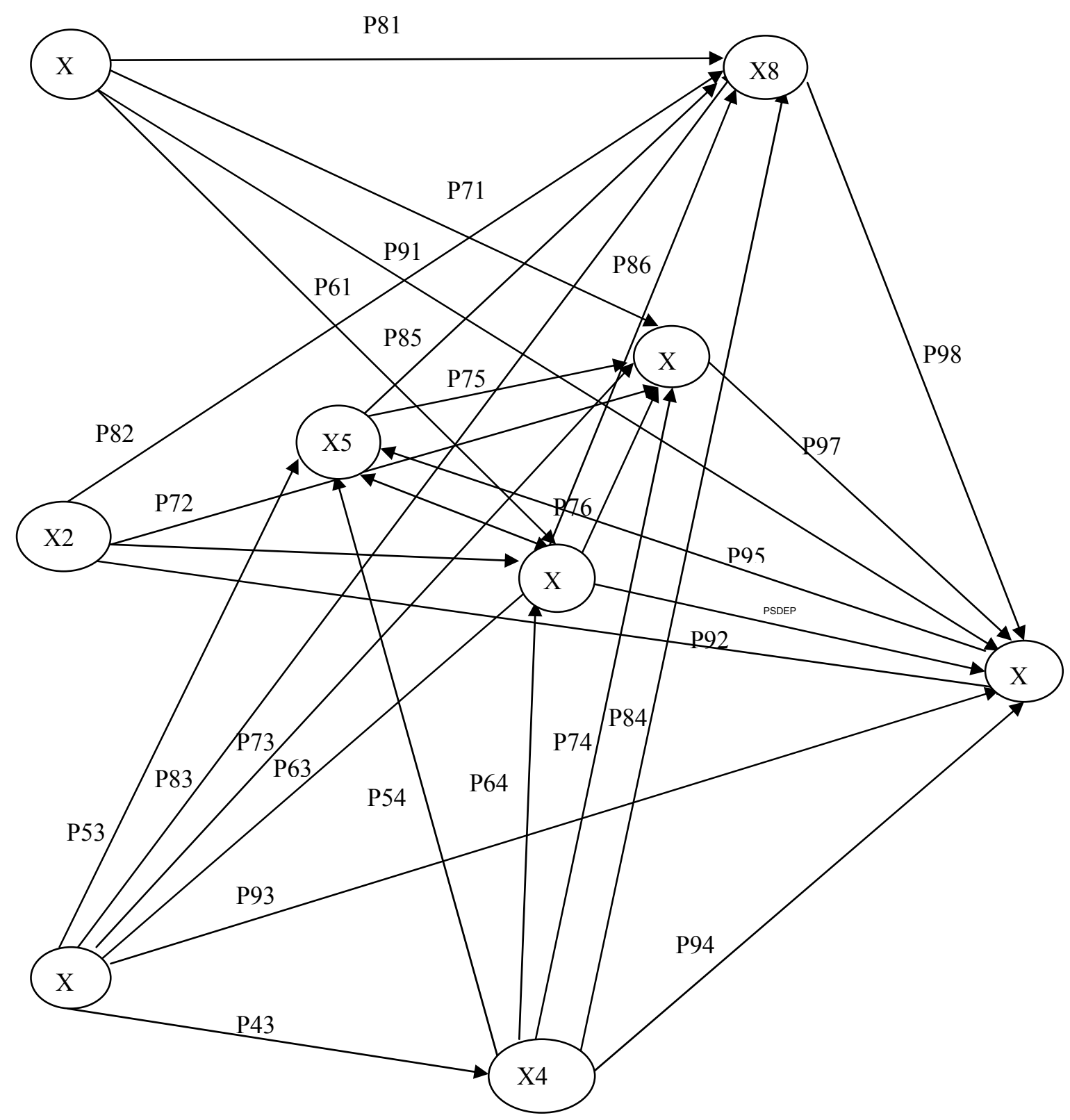

Figure 2. Hypothesized Causal Model 